\title{
The Initial Education of High School Teachers: A critical review of major issues and trends
}

\author{
Ronald G. Sultana \\ University of Malta, Malta
}

This paper draws on major research findings in international literature in order to provide a critical review of a number of key issues and trends in the initial education of high school teachers. Firstly, this paper contextualizes the prevalent discourse surrounding the field of initial teacher education (ITE) and explores the effect that this discourse has on the conceptualization of teachers' work. Secondly, this paper focuses on the debates regarding the most propitious site for the teacher education enterprise, the programme structure for ITE, the field placement or practicum, the relationship between subject study and pedagogy, and the overall effectiveness of teacher education. The paper concludes by considering the new challenges that the field of initial teacher education must confront and the implications of such challenges for the ITE curriculum.

\section{Contextualizing the Discourse of Initial Teacher Education}

The trends and issues in initial teacher education (ITE) that are identified in this paper are not free-floating, metaphysical entities. Rather, they are anchored in, and indeed emerge from, the prevailing economic, social, and cultural contexts that have marked the developed world in the transition to so-called post-Fordist, postindustrial, post-modern times. While the focus in this context is on the anglophone world, several of the developments in the UK, the USA, Canada, Australia, and New Zealand over the last 35 years are also visible internationally, albeit in different shapes and guises. Levitas (1986), Poppleton (1995), and Wain (2004), among others, have referred to the vigorous establishment during the 1980s and the 1990s of economic and cultural renewal/restructuring guided by what is often referred to as the New Right, or neo-conservatism. According to Brown, Halsey, Lauder, \& Stuart Wells (1997), this ideology welds together:

\footnotetext{
^Euro-Mediterranean Centre for Educational Research, University of Malta, Msida MSD 06, Malta. E-mail: Ronald.Sultana@um.edu.mt

ISSN 1742-5964 (print)/ISSN 1742-5972 (online)/05/020225-19

(C) 2005 Taylor \& Francis
}

DOI: $10.1080 / 17425960500288390$ 
a neo-liberal view of the virtues of individual freedom and the free market with a traditional conservative view that a strong state is necessary to keep moral and political order ... This could be seen as a "totalizing" modernist project, imposing the grand narrative of the market and competitive individualism as an instrument of cultural renewal. (p. 19)

According to a number of authors (e.g., Burbules \& Torres, 2000; Galbraith, 1992), the main features of the political economy of the New Right are (a) rolling back the frontiers of the state, because state intervention prejudices private enterprise and encourages dependency and a welfare mentality; (b) a commitment to the belief that economic and social renewal does not depend on state-led initiatives, but instead depends on changing the incentives for individuals; and (c) an understanding that the revitalization of nations depends not on Keynesian-style macroeconomic policy, but rather on microeconomic reform, through deregulatory strategies aimed at releasing market forces, particularly competition.

This and other developments in the economic realm-where the key themes are individual motivation, microeconomic change, the virtues of competition, and fiscal restraint-all have parallels in the restructuring of education. Briefly, the neo-liberal doctrine, when translated into the realm of schooling and education, leads to such policies as (a) the introduction of market competition in all education sectors, on the premise that with the appropriate incentives and market disciplines, such competition will raise standards and drive the inefficient out of business; (b) the devolution of financial, staffing, and policy issues to individual educational institutions that, in effect, become conceptualized as small to medium-sized businesses; (c) the view of educational service as a commodity under market conditions rather than as a public good, with parental choice of schools increasingly seen as a perfect way to satisfy "customers" and to ensure a competitive spirit between educational institutions; and (d) a diminishing interest in issues that have to do with an equitable distribution of social resources. The belief in an "enterprise culture" that underpins the new orthodoxy leads to an assumption that individuals will succeed if they are motivated enough to do so, and fails to recognize the dynamics of power between social groups.

Neo-liberal ideology in the educational field has several significant implications for the way that we view schools and teachers and, therefore, for what we consider the problems, challenges, and issues of ITE to be. One of the consequences of such an ideology is a mounting persuasion that schools can compete successfully irrespective of the nature of school intake. Another is the conviction that raising educational standards for all is largely a question of effective school management and quality teaching, completely ignoring the issues of the different social, economic, and cultural capital that students bring with them to the school and learning context. Educators inspired by neo-liberal perspectives tend to feel that a teacher's worth is to be measured by his or her ability to deliver good student results. Here the promise of rewards and differential remuneration, on the one hand, and the threat of dismissal on the other, are brought into play depending on whether the class and the school obtains good results in a sort of league table that pits educational communities against each 
other (Bates, 2004). Appeals to standards justify the intensification of school and teacher testing, leading to increased surveillance and control on the part of the state and education authorities in what has been termed "the age of standards" (Roth, 1996). Neo-liberal education policy-makers would tend to assume that the state employment of teachers leads to "provider capture"-a situation where employment is guaranteed because, through zoning and other strategies, student numbers are also guaranteed. According to neo-liberals, this encourages a non-competitive environment, with the security afforded by "civil servant status" working in favour of teachers rather than "the clients." The neo-liberal state therefore challenges teachers both individually and collectively (i.e., their unions), and it does this specifically by devolving responsibilities onto the school and the teacher, often in conditions of weakening budget provisions. The neo-liberal state also transfers greater power to parents and the community, to which teachers become increasingly accountable. At the same time, and despite this seeming devolution of power, the state maintains, and indeed tightens, its control over the curriculum and installs new forms of accountability and "performance indicators" in order both to change the practice of teaching and to regulate competition between institutions.

According to some (e.g., Carnoy, 1999; Stewart, 1996), the rise of a neo-liberal hegemony on a global scale is leading to an eclipse of concern with the social in education. The rise of neo-conservative ideology has also led to a diminishing financial commitment to addressing educational inequalities based on class, gender, and race, with many of the gains made over the past few decades by disadvantaged groups being lost in a climate that favours political and economic conservatism. There is an added, supra-national dimension to these transformations. These changes embedded in the global changes that mark the end of the Fordist phase of industrial societies as these give birth to the information-based economies; they are also expressed through supra-national entities such as the World Trade Organization, the World Bank, the OECD and the European Union (Laval \& Weber, 2002; Sultana, 2002a). Such changes and movements in the way the educational enterprise and discourse are constructed necessarily influence the conceptualization of ITE.

\section{Conceptualizing Teachers' Work}

In the light of both the background presented above and the different and sometimes conflicting images of teachers that societies have generated, it is critically important to audit the prevailing discourses, which have a major impact on the policies and practices that are adopted with regards to different aspects of the ITE enterprise. Teachers have been variously considered as artists (Delamont, 1995), clinicians (Calderhead, 1995), professionals (Hoyle, 1995), and researchers (Zeichner \& Noffke, 2001). Several other metaphors-among them the teacher as "gardener," for instance - can be culled from the broad range of literature on both teaching per se and the "helping professions" more generally. In this context, two points need to be considered. 


\section{Metaphors of Teaching and ITE Paradigms}

Our prevalent metaphor for the work of teachers-in other words, our conceptualization of teachers' work-has major implications for the way we go about preparing novices for the tasks of teaching. To illustrate, the early work of Jackson (1968), Eisner (1977) and Gage (1978) highlighted the distinction between teaching as a "science" (i.e., as a bundle of techniques), on the one hand, and teaching as an "art," on the other. All emphasize the indeterminate nature of teaching, which, like faith and spelling, is rather more "caught" than taught. This imagery leads consequentially to a specific notion of initial teacher education that emphasizes the careful choice of prospective candidates to ITE courses, because it follows that one is either "born" with "the flair" or not. This image also leads to the development of a course that emphasizes creativity, flexibility, experimentation, and self-expressive forms of teaching and learning. Furthermore, ITE course leaders who have the "teacher as artist" metaphor at the back of their minds will tend to eschew any formulaic approach to teaching how to teach: there are no recipe answers, and the greatest resource for the teacher is him/herself, rather more than any pre-set technique or strategy. Such imagery ties in with the developmentalist tradition that Zeichner (1993) identifies as one of the four key traditions of pre-service teacher education and training courses.

If, on the other hand, the prevalent image we hold in our head is that of teachers as "clinicians," then we will tend to emphasize the skills and techniques developed by "expert" and successful experienced teachers, in order to catalogue them and make them available to novices (e.g., through case-studies or micro-teaching sequences) and we will tend to view teacher education as a course in training in specific skills, with systematic attempts made to identify and root out incorrect and dysfunctional beliefs and habits in novice teachers. The "teacher as clinician" imagery connects with the "social efficiency" tradition in Zeichner's typology and is possibly best represented by the vogue for training articulated in terms of competencies (see Ryan, 1998; Tarrant, 2000).

The teacher-as-professional metaphor has led to attempts on the part of teacher educators to ensure that the sought-after parity of status with traditional professions is guaranteed through the development of ITE courses that reflect the location, duration, structure, standards, and occasionally even rituals of those courses that prepare medical doctors, lawyers, and natural scientists (Booth, Hargreaves, Bradley, \& Southworth, 1995). This approach is reflected in those ITE courses that are more firmly entrenched in what Zeichner refers to as the "academic tradition," where the liberal arts curriculum is adopted uncritically as a model.

Finally, the teacher-as-researcher metaphor leads to a very different kind of ITE course, one where teachers are considered to be "intellectuals" and as agents of change (Day, 2004; Smylie, Bay, \& Tozer, 1999) who have the cerebral and moral commitment to critically reflect on their own everyday practice as part of a wider and more intricate mesh of interactions between education and society. Courses inspired by this ideological vision reflect what Zeichner refers to as the "social 
reconstructionist" tradition in ITE, and one would expect to find a curriculum that accords great importance to the foundations disciplines-namely, sociology, philosophy, history, and economics of education, as well as policy studies. Such a curricular tradition would also privilege action research both as a method of assessment throughout the course and as a life-long habit and practice for intending teachers. It would consequently encourage teachers to engage in the wider public sphere, particularly in the major social movements that mould the political issues of their particular community.

\section{The Prevailing Paradigm in ITE}

Given the ideological context of neo-liberal discourse in education at the start of the third millennium, the most prevalent metaphor that structures the conceptualization of teachers' work today is arguably that of teachers as "clinicians." As Habermas (1971) has noted, "technocratic rationality" has increasingly colonized our life-world, and such a means-ends rationality has been generalized to include areas that were previously sheltered from the logic of the competitive "free" market. Increasingly, therefore, teachers' work is determined from "above," controlled and monitored in terms of criteria and accountability measures established with performance indicators in mind, with "teacher-proof packages" signalling the demise of the teacher as a professional, artist, or intellectual/researcher and the rise instead of the teacher as a "technician" (Hursh, 2000). The implications of this commitment to "technocratic modernization" (Young, 1998) for ITE courses are several, and a number of these are explored in some detail in the sections that follow. They can be usefully summarized in terms of trends towards (a) the shortening of the duration of teacher education courses (and hence the gradual falling out of favour of the 3- or 4-year education degree route and the privileging of the 1-year, exceptionally 2 -year postgraduate route, followed by a series of short in-service courses that aim to update specific skills); (b) the transfer of what is increasingly referred to as teacher training (not "education") to the school site, since learning to teach is a question of a craft apprenticeship to hardened practitioners; and (c) the emphasis on competency-based training.

\section{Sites for Learning to Teach}

Several reviews of teacher education programmes in Europe (e.g., Buchberger, Campos, Kallós, \& Stephenson, 2000; Sander, Buchberger, Greaves, \& Kallós, 1996) and internationally (e.g., Roth, 1999; Sultana, 2002b; UNESCO, 1998) generally identify the "universitization" of ITE as a key trend that has been apparent over the past two decades. Universitization of ITE connects, in many ways, with the promotion of the metaphor of "teaching as a profession" referred to earlier: by training alongside the traditional professions and making the earning of a degree a necessary prerequisite for joining the ranks of teachers, teacher unions could more easily claim parity of status with, say, lawyers and doctors, and better remuneration 
packages relative to what could be negotiated in the past (Johnson \& Boles, 2001). The experience of universitization of ITE has led to important debate (DarlingHammond, 1999; Furlong \& Smith, 1996), with critical issues being raised by scholars from a wide spectrum of ideological persuasions. There are several debatable matters here, and in point of fact there is an increasing lack of consensus as to whether the shift to university-based training has been beneficial, to the extent that not only is that trend being questioned, but also, in some cases (particularly the UK), even reversed.

There are several different aspects to this debate. There are those who have argued that the institutional culture of the university, which tends to reward research and publications rather more than it does teaching, has led to a situation where teacher educators "trade pedagogy for status." It could be said that the improvement in the quantity and quality of educational research carried out by faculty contributes directly and indirectly to the improvement of the teaching and learning enterprise more generally. Nevertheless, "theoreticization" and "academicization" have opened teacher education to criticisms of alienation from a hands-on engagement with the messy business in schools, and of a distraction from an "ethic of care" (Noddings, 2001) and the formation of the affective as against the merely cerebral dimensions of prospective teachers (Day, 2000).

Connecting with the earlier reference to the useful typology proposed by Zeichner, those critics inspired by a technocratic image of the teaching profession have argued that university-based teacher education tends to emphasize theory over practice, fails to get right the relationship between the disciplines and their application, and tends to be inordinately taken up with criticism rather than with helping students develop alternative forms of practice. ITE courses that take on board such a view have decreased the contribution of the foundations disciplines in the curriculum (Reid \& Parker, 1995), have emphasized competency-based training, have restructured the location of staff from being office-based to being increasingly school-based, and have adopted apprenticeship-type approaches in field placement practices, including some form of mentoring. In this sense, while teacher education seems to be located in universities in the formal sense, staff and students are spending an increasingly large percentage of their time at school, with significant input being made by regular teachers who act as models (presumably of good practice) and by tutors.

Leaders of courses who have been rather more inspired by the developmentalist, personalistic tradition of ITE have reacted against what they see to be the excessive emphasis on academic competence in the preparation of teachers. A contrast is often drawn with the "seminaristic tradition" that prevailed in teachers' colleges, where generally speaking the affective socialization of teachers into the profession was given paramount importance, in the belief that personal qualities were at least as important as academic knowledge in the teaching-learning nexus. While it could be argued that the interaction between prospective teachers with students from other faculties on the same campus provides qualitatively superior opportunities for informal personal development than does the "cocoon" type of socialization offered by teachers' colleges, it seems to be the case that systematically planned "formation" of the set of 
personal characteristics deemed suitable for teaching is weak in university-based courses.

Partly as a result of the neo-liberal/New Right suspicion of "left-wing" criticism in academia, but also as a reaction to the perceived distance between the training offered in a university setting and the "real needs" of schools, the idea of having student teachers and faculty staff spending more time in schools becomes more appealing. On their part, teacher education leaders inspired by the emancipatory, socialreconstructionist tradition of pre-service courses emphasize the dangers with such apprenticeship models, noting that school-based teacher training often leads to a preoccupation with "what works" and with classroom management, and may even lead into an apprenticeship into mediocrity. In such models, consideration of ethical, political, and moral issues related to teaching tend to be eschewed (Hansen, 2001). Emancipatory teacher educators would question a solution that would locate the initial preparation of teachers wholly in the schools and argue for a continued, if reconsidered, university connection.

\section{The Programme Structure in ITE}

The EURYDICE (2002) publication on the initial training of teachers across Europe leads one to conclude that there is simply not enough evidence to suggest that there is any "one best model" of teacher education. This conclusion applies both to the relationship between subject content knowledge and methodology in the campus experience and to the percentage of time allocated to the different elements that make up the programme, i.e., to subject-matter studies, foundation of education studies, professional studies (including methodology and curriculum courses and courses based on knowledge generated through research on teaching), and field placement (including school experience and teaching practice). The focus here is on the debates surrounding the advantages and disadvantages of having a concurrent or a consecutive type of ITE course for prospective high school teachers. This needs to be premised by pointing out that the debate is not new: indeed, as Borrowman's (1965) historical analysis suggests, the issue of the "right" mix-quantitatively and qualitatively speaking-between liberal and professional studies has been central to the development of the ITE field from the mid-nineteenth century.

Consecutive courses are typically structured around a 3- or 4-year liberal education programme, followed by a fourth or fifth year of highly professional training. A recent development has seen teacher education becoming a postgraduate enterprise - a 3- or 4 -year degree in arts or science, followed by a 2-year master's in teaching. Those who favour consecutive courses highlight the fact that they encourage single-mindedness of purpose within an institutional unit. Critics point out the dangers of having subject content specialists ignoring professional concerns, as well as those areas of the substantive framework required by teachers (cf. Grossman, Wilson, \& Shulman, 1989). Having renounced any responsibility for subject content, methodologists will most likely focus solely on the relevance of their contribution to classroom teaching. 
On their part, concurrent programmes select studies for their concomitantly liberal and professional ends, organizing them around a set of professional functions of teaching or a general social problems core. While the treatment of subject matter in a way that relates it to pedagogic issues may yield more valid and useful knowledge for prospective teachers, concurrent courses require more co-operation among potentially hostile faculty staff. Moreover, the fact that subject matter studies and professional studies are taught concurrently does not automatically mean that the two areas are related in any pedagogically fruitful manner in the prospective teachers mind, that is, through the development of pedagogic content knowledge.

Despite the fact that the debate has not found any epistemological consensus, Grimmett (1998) points out that American-influenced reform thinking has led to an uncritical acceptance of the dominance of the consecutive model. Reflecting on the Canadian context, Grimmett instead calls for teacher preparation that is located in collaborative partnerships between faculties of education and the field, on the one hand (through the engagement of pre-service teachers in action research into dilemmas of teaching), and between faculties of education and university faculties of arts and science, on the other.

Increasingly, however, and under the influence of the internationally renowned reports of the Holmes Group (1986) and of the Carnegie Forum on Education and the Economy (Carnegie Forum on Education and Economy Task Force on Teaching as a Profession, 1986), the idea of all teacher education becoming a postgraduate training enterprise-that is, master's-level courses building consecutively on substantive study in the arts and sciences at the undergraduate level-is being adopted (or recommended) by several universities in America (Gimmestad \& Hall, 1995) and elsewhere (Jarrar, 2002; Snook, 1998).

\section{The Practicum}

While there is much that is debated in the field of ITE, there is a consensus around the fact that the various forms of school experience and field placements constitute the central elements in preparing to become a teacher (Ben-Peretz, 1995; Moon, 1996). That centrality comes through in many ways, among them being the proportion of curriculum time dedicated to field experience and the fact that ITE students value field experience above any other aspect of their course (e.g., Tisher, 1990), a position that is also grounded in the belief that teaching is learnt from experience, or not at all. There is also an international trend towards increasing the time devoted to teaching practice, in terms of both direct field placements and school-based ITE (Moon, 1996). This is often accompanied by an attempt to link other aspects of the ITE curriculum - including foundational studies - to the practical concerns of classroom life and to provide opportunities for indirect practice in classes or workshops in teacher training institutions.

Despite the generally held assumption that field experience is a good thing, research has begun to reveal some unexpected negative learning from this curricular emphasis on placements in schools and classrooms (Edmundson, 1990). Field practice tends to 
foster a "group management" orientation, in contrast to an "intellectual leader" orientation in teachers' thinking about their work, often at the expense of a concern with student learning. ITE students also tend to adopt a view that the way to learn more about teaching is through trial and error, not careful thought and scholarship: what matters is which strategy gives the expected results in the least time possible. Furthermore, for most students on their field placements, survival is uppermost on their minds, and there is very little engagement with the theoretical principles necessary to understand social and ethical issues in teaching, how children learn, how curriculum decisions might be guided, and how students' cognitions might influence teaching (Dewey, 1974). Finally, interaction with experienced teachers, while potentially fruitful, tends to lead ITE students to become conservative in their approach to the complex challenges of teaching. Instead of responsibility and reflection, acquiescence and conformity to school routines become the order of the day.

In contrast, the goals for school-site practical experiences expressed by many ITE institutions include increased awareness of students' knowledge and beliefs about pupils and classrooms, reconstruction of idealized and inaccurate images of pupils and of self-as-teacher, shifts in attention from self to instructional issues and then to pupil learning, development of standardized routines for management and instruction, and development of problem-solving skills that are multidimensional and context-specific.

The value of school placements clearly depends on the kind of preparation that students receive before they are sent to the field, the kind of supervision and feedback that they are provided with throughout the field experience, the kind of teacher mentors to whom they are apprenticed, and the quality of theoretically informed reflection that students engage in as they go about their work in schools and classrooms. Over the past decade and a half, developments in thinking and in innovations in this area have attempted to address these different aspects that can make a positive difference to the way field placements impact on the formation of teachers, and to improving the dynamic link between theory and practice. One of the more significant of these developments involves the increasing use of school-based mentors as a way to value the craft knowledge of experienced teachers in the formation of novices (Fletcher, 2000; Furlong \& Maynard, 1995). Mentoring has, in the best of cases, evolved and matured into a collaborative effort on the part of faculty and schools to create a supportive environment to ITE students, where a community of shared inquiry and learning is created on the basis of field observations and experiences (Whitehead, 1995).

Related to the popularity of the idea of mentoring is the concomitant rise of Professional Development Schools (PDS), particularly in the USA where PDSs are seen, according to Arends and Winitizky (1996), to

serve as a field placement site for teacher candidates, to promote the professional development of experienced teachers, and to advance the knowledge base on teaching and learning by supporting reflection, inquiry and research ... by focusing on such 
system-level change, meaningful reform for both schools and teacher education can take place. (p. 543)

There are mixed reviews and results in terms of the ability of PDS to deliver in all these areas, as Whitford and Metcalf-Turner (1999) make amply clear. Nevertheless, despite the magnitude of the tasks they are attempting to fulfil-namely, to change the personality of an occupation and the character of two well-established institutions (Stallings, Knight, \& Wiseman, 1995)_PDS seem to provide an increasingly attractive way of responding to what are often contrasting demands made by universities on the one hand and schools on the other.

Further developments aiming at strengthening the link between the theoretical and practical elements of teacher education courses include the promotion of reflective journals, the preparation of portfolios, and the carrying out of action research. These strategies encourage students to investigate "critical incidents" and dilemmas that they encounter during their field placement, in such a way that the link between theory and practice is articulated in an increasingly sophisticated manner. This fosters the development of the qualities required by the "reflective practitioner" (Schön, 1987), whereby strategies and techniques are evolved to deal with the complex, uncertain, unstable, and unique situations of the teaching practice.

The idea of reflective practice is intimately linked to the notion of a community of practice and to teacher collegiality, whereby professionalism evolves through participation in the active learning communities of teachers. Such professional development can be facilitated through conferencing between, for instance, university tutors, school-based mentors/co-operating teachers, and student teachers in collegial settings that set high standards, providing a dynamic interchange that draws on the strengths of all the partners in addressing pedagogical and curricular issues.

\section{The Relationship between Subject Study and Pedagogy}

The issue of the relationship between knowledge of content and competence in facilitating learning of that content is of major relevance and importance to postprimary ITE, yet the issue is only rarely dealt with (see McNamara, 1991, 1994), particularly in the UK context, where teacher education has largely become a fleeting, postgraduate affair, generally isolated from the subject-matter faculties. Mayer-Smith (1998), for instance, points out the virtually complete absence internationally of research that examines the influence of teaching by academic subject-matter professors on the entering pedagogical beliefs of pre-service teachers. Grossman, Wilson, and Shulman (1989), in what is still arguably the leading conceptual piece on the issue of subject-matter knowledge for teaching, note that teacher educators remand responsibility for the transmission of knowledge to departments of arts and sciences, apparently unaware that there are several dimensions of subject-matter knowledge that are particularly important to the task of teaching.

One of these dimensions refers to the need to guarantee that student teachers of a particular subject or area have been exposed to the "substantive structure" 
of a particular domain, that is, that they are sufficiently aware of the paradigmatic reach or framework of that field. This does not mean that they have to know "everything" there is to know about the subject, but that they are aware of its breadth and depth. This also means that student teachers have to be well-versed in the "syntactic structure" of their particular domain, that is, they have to know about the methods through which knowledge in that area is produced. This is vital since the modern curriculum is characterized by open-endedness and innovation, and the teacher must be able to research new knowledge as it is produced, and also be involved in its production.

There are very important pedagogic implications for the extent and depth of knowledge of subject matter on the part of teachers. Drawing on several studies in this area, McDiarmid, Ball, \& Anderson (1989) argue that lack of depth of knowledge of subject matter tends to lead a teacher to closely control the framing of a particular learning session, in order to ensure that students do not lead him or her into unfamiliar or uncomfortable areas. Such teachers tend to avoid openquestion techniques, for instance, preferring teacher-led discussion instead.

Awareness that the curricular diet offered by faculties of arts and sciences to teacher education students is not necessarily what the latter require does not imply that the ITE subject matter curriculum should reflect the curriculum of the schools in which student-teachers will teach. Rather, it is a point made in connection to the requirements of coverage and mastery of both the substantive and syntactic structures referred to earlier. There is no automatic guarantee that "servicing faculties" necessarily deliver in that regard. In addition, there are aspects of a particular domain which servicing faculties are unlikely to teach, but which have special relevance to prospective teachers (e.g., children's literature).

Another element worth highlighting is an early Deweyan insight that while what a teacher needs to know about a subject often overlaps with the knowledge of scholars of that discipline, teachers nevertheless need also to understand their subject matter in ways that promote learning. Not only do teachers need to have a firm grasp of the substance and syntax of their subjects, they are also required to have knowledge of learners and learning, of curriculum and context, of aims and objectives, and of pedagogy. In particular, Shulman (1986) argues that teachers need to have "pedagogical content knowledge", which he describes as including "the most useful forms of representation of ... ideas, the most powerful analogies, illustrations, examples, explanations, and demonstrations-in a word, the ways of representing and formulating the subject that makes it comprehensible to others" (p. 6.)

Grossman et al. (1989, p. 32) argued in favour of the reunion of pedagogy and content in ITE courses. The difficulties with this approach are enormous, not only because of the already-noted move towards consecutive programmes internationally, but also because of the clear evidence of hierarchical relations in most universities that have teacher education components (Furlong \& Smith, 1996), with subject-matter specialists often assuming that they are more endowed with the qualities that are normally associated with prestige in universities. 


\section{The Effectiveness of Teacher Education}

Perhaps the most disheartening news for teacher educators is the overwhelming evidence of their ineffectiveness. There are now a large number of studies attesting to the fact that, for a number of reasons, prospective teachers learn much more from their "apprenticeship of observation" (Lortie, 1975) and the "cumulative experience of school lives" (Britzman, 1986) than from what is taught during ITE courses (Raths, 2001). Pre-service teachers do not typically develop new perspectives, but simply become more skilled at defending the perspectives they already possess (Stofflett \& Stoddart, 1992). Prior beliefs act as filters to screen out programme experiences that are cognitively incompatible (Holt-Reynolds, 1992). The general belief and attitudes brought to an ITE course by the typical student teacher is that there is little to learn about teaching, that what there is to learn is best learnt through experience, that one either is a good teacher or one is not (and that therefore innate skills and instinct rather than training will make the difference), and that "teaching personality" rather than cognitive skills or pedagogical or subject-matter knowledge is what matters most of all (Sugrue, 1996). They tend to leave the ITE course thinking that the ideas and methods emphasized do not accord well with the challenges subsequently met in the classroom.

Prospective teachers' beliefs and attitudes prior to embarking on a teacher training and teaching career are of crucial relevance in developing effective strategies in learning to teach (Pajares, 1992; Richardson, 1996). Indeed, Carter (1990) identifies a shift in the learning-to-teach literature that occurred in the mid-1980s, namely one that, rather than emphasizing what teachers should know and how they should best be trained to know it, highlighted instead the importance of understanding what they actually did know and how that knowledge was acquired. While some have made a case for restructuring teacher education curricula in such a way as to challenge such prior beliefs (cf. the critical review by Artiles, Trent, \& Kuan, 1996), others-perhaps more logically given the evidence of the enduring quality of such beliefs-have suggested that an alternative to changing beliefs is to build on those that already exist (Burn, Hagger, Mutton, \& Everton, 2000; Calderhead, 1996). In this sense, teacher education programmes, both pre-service and in-service, would strive towards the construction of teaching from the perspectives of teachers themselves through the exploration of the "professional craft knowledge."

While critically important, such low expectations prior to starting an ITE course and such negative evaluations of the course once it is terminated need nevertheless to be problematized. Not only do they generally rely on self-report-type studies, they also could be a function of unrealistic expectations. Many seem to fail to realize that there are no recipe formulas to teaching, and comfortable though it might be to have what Greene (1979) refers to as a "technology of teaching," it is the case that "general principles never fully apply to new and special situations, especially if those principles are thought of as prescriptions or rules ... as well all know, classroom situations are always new and never twice alike" (pp. 27-28). In addition, there seems to be some evidence that professional teacher preparation does make a positive difference to the teaching and learning process. As Wideen, Mayer-Smith, \& Moon (1998, p. 144) 
conclude in their review of the literature, "the fixed nature of prospective teachers' beliefs should remain an open question rather than an accepted assumption until the impact of the more robust programs of teacher education has been fully analyzed."

\section{New Challenges to ITE and Implications for the ITE Curriculum}

In this final section, the focus is on new challenges to ITE, given the changing nature of knowledge and the changing nature of societies. Governments tend to regard formal education as a key strategy in shaping a nation and preparing it for what are perceived to be sets of new challenges. We must be aware that governments will attempt to manage economic and other crises by "exporting" them on to vulnerable sections of society; teaching and schools have been more than once proved to be perfect scapegoats in this exercise. The fact remains that education must be responsive to new societal realities, trends, and "needs" (while remaining critically sensitive to the fact that "needs" are anchored in a socially constructed discourse that is never politically innocent). Indeed, education may well have to be proactive and prevoyant, straddling the occasionally contradictory roles of both reproducing and producing society. In this context, attention is briefly drawn to some of the most relevant elements in this debate.

One could here refer to the open-ended quality of knowledge in an information society: the implications for ITE include the need for focused curricular efforts to help prospective teachers make a shift from insular to connective specialization and to socialize them into the habit of lifelong learning, where professional development goes on from the stages of novice and beginning teacher throughout one's teaching career (Day, 1999). Linked to this is the need for teachers to have skills in research, that is, that they not only know how to find and manage knowledge, but also to appraise it critically and, ultimately, to produce it. The implication is that ITE courses should have a research component that is formally integrated into the curriculum through the kinds of course assignments and projects given, through action research during field placements, and/or through the dissertation requirement. This is particularly critical given "new" notions of professionalism and also our changing understanding of what it means to learn. Such shifts are underpinned by constructivist approaches as well as by an increased appreciation of the dynamics of situated cognition, whereby it is the context and activities through which knowledge is acquired that render it meaningful. It follows that prospective and experienced teachers must be helped to develop the intellectual skills to reason about their work in the process of doing it (De Jong, Korthagen, \& Wubbels, 1998), to articulate their own "personal" theories and to participate in whole school development through public communities of inquiry. No longer should there be the Carthesian, positivistic divide between universities as providing "propositional knowledge" (knowledge that), and schools providing "procedural knowledge" (knowledge how), which is the implicit theoretical approach underlying many traditional ITE courses (see Ethell, 1998). Rather, what one should envisage are new types of relationships between schools and universities as both try to respond to the challenge of reflexive modernization by becoming learning organizations. 
A key challenge concerns the attitudes and skills needed to deal with diversity. As stated succinctly by Wideen et al. (1998, p. 168), the issue here involves preparing "an increasingly homogeneous population of beginning teachers ... to teach an increasingly heterogeneous population of students." This issue of diversity has at least four aspects: demography, multiple intelligences, inclusion, and gender. Demography is relevant in the sense that societies are indeed becoming more multicultural. Thanks to the influence of Vygotskian psychology, most recently popularized by Gardner's (1993) propositions about "multiple intelligences," the increasingly accepted view is that all students are capable of learning and hence teachers must adapt their teaching style to match the type (not "amount") of intelligence and learning style of their students. For many education systems, this is nothing short of a paradigmatic shift in the way the learning enterprise is conceptualized and, by implication, the way prospective teachers are prepared to teach. Linked to this is the increasingly accepted idea of inclusion (Phtiaka, 2001). In several national contexts, the movement towards the inclusion of learners with disabilities in so-called "mainstream" schooling has been successful, with politically and economically expedient integration policies running faster than ITE and inservice providers in preparing teachers for the challenging task.

By no means least important is the pivotal issue of gender in ITE. Mention has already been made of the way the neo-liberal swing has negatively affected the gender equity agendas in education. As with other aspects of diversity, gender challenges a number of "givens" in teacher education: it questions prevalent curricular emphases and biases; it confronts the gendered positioning and representation of a number of high school subjects; it problematizes the overall context as well as the socialization experience offered en route to becoming a teacher. As Weiler (1997) has pointed out, it defies the very ideology underpinning the representation of teaching as a "profession," with its connotations of elite knowledge that is quantifiable, objective, and abstract.

Most crystal ball-gazing exercises about the presumed "future" of ITE refer to the impact of information technology on the preparation of prospective teachers. Moon (1997) speaks of a "new paradigm" for teacher development, with new interactive forms of technology having a "crucial, perhaps major, role to play" (p. 7). Certainly there is consensus that ITE graduates should be computer-literate and aware of the impact-both positive and negative-that technology can have on the learning process, not least in terms of the organization of the enterprise to include different "types" of learners, as stated earlier. Noting the impressive congruence among the main contemporary psychological perspectives on learning, namely that "good learning is a process of socially based, active co-construction of contextualized knowledge and webs of relations among nodes," Salomon and Almog (1998, p. 229) argue that the new learning environments require a number of major shifts. These are a conceptual and cultural shift from teacher-led instruction to an interactive community of learners, from a highly structured curriculum to an emerging, often improvised one, from knowledge as the accumulation of discrete units to the tackling of whole issues, and from the acquisition of handed-down knowledge to the handling of information to be sought and processed. Aspects of these shifts have already been 
referred to throughout this paper. What is important in this context is the authors' claim that such shifts towards novel learning environments greatly depend on the availability of technology. Salomon and Almog conclude

It would be most difficult to create the kind of team-based, interdisciplinary problemsolving and information-rich learning environment ... mentioned earlier in the absence of technology-enhanced search for relevant information, computerized lab simulations, data collection and analyses, semi-intelligent tools for design and presentation, communication, and the like. (p. 238)

It is nevertheless critical to emphasize the point made by Papert (1987) that the more quickly new technologies of communication have been integrated into the teaching/learning nexus, the more easily they seem to have become co-opted in the mainstream educational paradigm, that is, top-down delivery systems that fail to recognize real differences among learners.

\section{Concluding Comments}

In identifying some of the key issues and trends in initial preparation of high school teachers, a number of broad aims have been achieved. First, the coverage of the literature is sufficiently extensive to give a clear sense of the themes and debates that mark the field and that are among the most central. Second, critical engagement with current realities should serve to guide teacher educators as they consider the important work they do in preparing tomorrow's educators. The emphasis here is on providing enough elements that encourage individual reflection. However, this review has its origins in the communal reflection of a faculty contemplating teacher education reform and it has been written in the same spirit, that is, in the hope that it will encourage collegial debate in a faculty milieu conceptualized as a community of critical inquiry. Finally, in constantly referring to the context in which ideas and practices arise, I have attempted to ensure that "issues" and "trends" do not appear as disembodied and fortuitous movements, but rather as reflections of deeper dynamics that have to do with politics and power. In that sense, teacher education, like all enterprises purporting to be educational, has to be considered as a moral activity (Hansen, 2001), and as such must come to terms with questions of social justice, representation, voice, and equity. In striving to be both technically and morally competent, initial teacher education can hope to meet some of the most pressing challenges in the preparation of future generations of teachers in ways that are both positive and caring.

\section{References}

Arends, R., \& Winitzky, N. (1996). Program structures and learning to teach. In F. B. Murray (Ed.), The teacher educators' handbook: Building a knowledge base for the preparation of teachers (pp. 526-556). San Francisco: Jossey Bass.

Artiles, A. J., Trent, S. C., \& Kuan, L. I. (1996). The preservice education of teachers for student diversity: An analysis of the special education empirical literature. Paper presented at the meeting of the American Educational Research Association, Chicago. 
Bates, R. (2004). Regulation and autonomy in teacher education: Government, community or democracy? Fournal of Education for Teaching: International Research and Pedagogy, 30(2), $117-130$.

Ben-Peretz, M. (1995). Curriculum of teacher education programs. In L. W. Anderson (Ed.), International encyclopedia of teaching and teacher education (2nd ed., pp. 543-547). Oxford, England: Pergamon.

Booth, M., Hargreaves, D. H., Bradley, H., \& Southworth, G. (1995). Training of doctors in hospitals: A comparison of teacher education. Fournal of Education for Teaching, 21(2), $145-161$.

Borrowman, M. L. (1965). Teacher education in America: A documentary history. New York: Teachers College Press.

Britzman, D. P. (1986). Cultural myths in the making of a teacher: Biography and social structure in teacher education. Harvard Educational Review, 56, 442-456.

Brown, P., Halsey, A. H., Lauder, H. \& Stuart Wells, A. (1997). The transformation of education and society: An introduction. In A. H. Halsey, H. Lauder, P. Brown, \& A. Stuart Wells (Eds.), Education: Culture, economy and society (pp. 1-44). Oxford, England: Oxford University Press.

Buchberger, F., Campos, B. P., Kallos, D. \& Stephenson, J. (2000). Green paper on teacher education in Europe. High quality teacher education for high quality education and training. Thematic Network on Teacher Education in Europe. Retrieved January 8, 2005, from http://tntee. umu.se/

Burbules, N. C., \& Torres, C. A. (2000). Globalization and education: Critical perspectives. London: Routledge.

Burn, K., Hagger, H., Mutton, T., \& Everton, T. (2000). Beyond concerns with the self: The sophisticated thinking of beginning student teachers. Fournal of Education for Teaching, 26, $259-278$.

Calderhead, J. (1995). Teachers as clinicians. In L. W. Anderson (Ed.), International encyclopedia of teaching and teacher education (2nd ed., pp. 9-11). Oxford, England: Pergamon.

Calderhead, J. (1996). Teachers' beliefs and knowledge. In D. C. Berliner, \& R. C. Calfee (Eds.), Handbook of educational psychology (pp. 709-725). New York: Macmillan.

Carnegie Forum on Education and Economy Task Force on Teaching as a Profession. (1986). A nation prepared: Teachers for the 21st century. New York: Carnegie Forum on Education and the Economy.

Carnoy, M. (1999). Globalization and educational reform: What planners need to know. Paris: UNESCO, IIEP.

Carter, K. (1990). Teachers' knowledge and learning to teach. In W. R. Houston, M. Haberman, \& J. Sikula (Eds.), Handbook of research on teacher education (pp. 291-310). New York: Macmillan.

Darling-Hammond, L. (1999). The case for university-based teacher education. In R. A. Roth (Ed.), The role of the university in the preparation of teachers (pp. 13-30). London: Falmer Press.

Day, C. (1999). Developing teachers: The challenges of lifelong learning. London: Falmer Press.

Day, C. (2000). Teachers in the twenty-first century: Time to renew the vision. Teachers and Teaching: Theory and Practice, 6, 101-115.

Day, C. (2004). Change agendas: The roles of teacher educators. Teaching Education, 15, 145-158.

De Jong, J., Korthagen, F., \& Wubbels, T. (1998). Learning from practice in teacher education: Processes and interventions. Teachers and Teaching: Theory and Practice, 4, 47-64.

Delamont, S. (1995). Teachers as artists. In L. W. Anderson (Ed.), International encyclopedia of teaching and teacher education (2nd ed., pp. 6-8). Oxford, England: Pergamon.

Dewey, J. (1974). The relation of theory to practice in education. In R. D. Archambault (Ed.), fohn Dewey on education: Selected writings (pp. 313-339). Chicago: University of Chicago Press.

Edmundson, P. G. (1990). A normative look at the curriculum in teacher education. Phi Delta Kappan, 71, 717-722. 
Eisner, E. (1977). On the uses of educational conoisseurship and educational criticism for evaluating classroom life. Teachers College Record, 78, 345-358.

Ethell, R. (1998, December). Reconciling propositional and procedural knowledge: Beginning teachers' knowledge-in-action. Paper presented at the meeting of the New Zealand Association for Research in Education.

EURYDICE. (2002). The teaching profession in Europe: Profiles, trends, concerns: Report 1-Initial training and transition to working life. Brussels, Belgium: Author.

Fletcher, S. (2000). Mentoring in schools. London: Kogan Page.

Furlong, J., \& Maynard, T. (1995). Mentoring student teachers: The growth of professional knowledge. London: Routledge.

Furlong, J., \& Smith, R. (1996). The role of higher education in initial teacher training. London: Kogan Page.

Gage, N. L. (1978). The scientific basis of the art of teaching. New York: Teachers College Press.

Galbraith, J. (1992). The culture of contentment. London: Sinclair-Stevenson.

Gardner, H. (1993). The unschooled mind: How children think and how schools should teach. London: Fontana.

Gimmestad, M. J., \& Hall, G. E. (1995). Structure of teacher education programs. In L. W. Anderson (Ed.), International encyclopedia of teaching and teacher education (2nd ed., pp. 548-552). Oxford, England: Pergamon.

Greene, M. (1979). Teaching: The question of personal reality. In A. Lieberman, \& L. Miller (Eds.), Staff development: New demands, new realities, new perspectives (pp. 23-35). New York: Teachers College Press.

Grimmett, P. P. (1998). Reconceptualizing the practice of teacher preparation: On not throwing out the concurrent model with the reform bathwater. Alberta fournal of Educational Research, 44, $251-267$.

Grossman, P. L., Wilson, S. M., \& Shulman, L. S. (1989). Teachers of substance: Subject matter knowledge for teaching. In M. C. Reynolds (Ed.), Knowledge base for the beginning teacher (pp. 23-36). Oxford, England: Pergamon.

Habermas, J. (1971). Knowledge and human interests. London: Heinemann.

Hansen, D. T. (2001). Teaching as a moral activity. In V. Richardson (Ed.) (4th ed., pp. 826-857). Washington, DC: American Educational Research Association.

Holmes Group. (1986). Tomorrow's teachers. East Lansing, MI: Author.

Holt-Reynolds, D. (1992). Personal history-based beliefs as relevant prior knowledge in coursework: Can we practice what we teach? American Educational Research Fournal, 29, $325-349$.

Hoyle, E. (1995). Teachers as professionals. In L. W. Anderson (Ed.), International encyclopedia of teaching and teacher education (2nd ed., pp. 11-15). Oxford, England: Pergamon.

Hursh, D. (2000). Neoliberalism and the control of teachers, students and learning: The rise of standards, standardization, and accountability. Cultural Logic, 4(1). Retrieved March 31, 2005, from http://eserve.org/clogic/4-1/hursh.html.

Jackson, P. W. (1968). Life in classrooms. New York: Holt, Rinehart \& Winston.

Jarrar, S. A. (2002). Teacher education in the Arab world: The key to the 21 st Century. In R. G. Sultana (Ed.), Teacher education in the Euro-Mediterranean region (pp. 1-24). New York: Peter Lang.

Johnson, S. M., \& Boles, K. C. (2001). The power of collective action: A century of teachers organizing for education. In V. Richardson (Ed.), Handbook of research on teaching (4th ed., pp. 858-876). Washington, DC: American Educational Research Assocation.

Laval, C., \& Weber, L. (2002). Le nouvel ordre éducatif mondial: OMC, Banque Mondiale, OCDE, Commission Européenne. Paris: Nouveaux Regards.

Levitas, R (Ed.) (1986). The ideology of the new right. Cambridge, England: Polity.

Lortie, D. (1975). Schoolteacher. Chicago: Chicago University Press. 
Mayer-Smith, J. (1998). Opening Pandora's box: On bridging the divide between the providers of teacher education in the faculties of education and science. Paper presented at the meeting of the Canadian Society for the Study of Education, Ottawa.

McDiarmid, G. W., Ball, D. L., \& Anderson, C. W. (1989). Why staying one chapter ahead doesn't really work: Subject-specific pedagogy. In M. C. Reynolds (Ed.), Knowledge base for the beginning teacher (pp. 193-205). Oxford, England: Pergamon.

McNamara, D. (1991). Subject knowledge and its application. Fournal of Education for Teaching, 17(2), 113-127.

McNamara, D. (1994). Subject study in teacher education. In G. Harvard, \& P. Hodkinson (Eds.), Action and reflection in teacher education (pp. 229-245). Norwood, NJ: Ablex.

Moon, B. (1996). Practical experience in teacher education: Charting a European agenda. European Fournal of Teacher Education, 19(3), 217-231.

Moon, B. (1997). Open learning and new technologies in teacher education: New paradigms for development. European fournal of Teacher Education, 20(1), 7-31.

Noddings, N. (2001). The caring teacher. In V. Richardson (Ed.), Handbook of research on teaching (4th ed., pp. 99-105). Washington, DC: American Educational Research Association.

Pajares, M. F. (1992). Teachers' beliefs and education research: Clearing up a messy construct. Review of Educational Research, 62, 307-332.

Papert, S. (1987). Computer criticism vs. technocratic thinking. Educational Researcher, 16(1), $22-30$.

Phtiaka, H. (Ed.) (2001). Special and inclusive education in the Mediterranean region [Special issue]. Mediterranean Fournal of Educational Studies, 6(2).

Poppleton, P. (1995). Teacher education and the market economy in Britain. In R. Hoz, \& M. Silberstein (Eds.), Partnerships of schools and institutions of higher education in teacher development. Tel Aviv, Israel: Ben Gurion University of the Negev Press.

Raths, J. (2001). Teachers' beliefs and teaching beliefs. Early Childhood Research and Practice, 3(1), Retrieved March 31, 2005, from http://ecrp.uiuc.edu/v3n1/raths.html

Reid, I., \& Parker, F. (1995). Whatever happened to the sociology of education in teacher education? Educational Studies, 21(3), 395-413.

Richardson, V. (1996). The role of attitude and beliefs in learning to teach. In J. Sikula, T. Buttery, \& E. Guyton (Eds.), Handbook of research on teacher education (2nd ed., pp. 102-119). New York: Macmillan.

Roth, A. R. (1996). Standards for certification, licensure and accreditation. In J. Sikula, T. J. Buttery, \& E. Guton (Eds.), Handbook of research on teacher education, 2nd edn. (pp. 242-306). New York: Macmillan.

Roth, A. R. (Ed.) (1999). The role of the university in the preparation of teachers. London: Falmer Press.

Ryan, B. (1998). Competency-based reforms to Australian teaching: The last rites for social democracy. Fournal of Education Policy, 13(1), 91-113.

Salomon, G., \& Almog, T. (1998). Educational psychology and technology: A matter of reciprocal relations. Teachers College Record, 100, 222-241.

Sander, T., Buchberger, F., Greaves, A. E., \& Kallós, D. (Eds.) (1996). Teacher education in Europe: Evaluation and perspectives (2nd ed.) Osnabrück, Germany: Universitat Osnabrück.

Schön, D. A. (1987). Educating the reflective practitioner. Toward a new design for teaching and learning in the professions. San Francisco: Jossey-Bass.

Shulman, L. S. (1986). Those who understand: Knowledge growth in teaching. Educational Researcher, 15(2), 4-14.

Smylie, M. A., Bay, M., \& Tozer, S. E. (1999). Preparing teachers as agents of change. In G. A. Griffin (Ed.), The education of teachers (98th yearbook of the National Society for the Study of Education, part 1 (pp. 29-62). Chicago: University of Chicago Press.

Snook, I. (1998, October). Teacher education: Can it lead to a learned profession? Paper presented at the meeting of the New Zealand Council for Teacher Education, Hamilton, New Zealand. 
Stallings, J. A., Knight, S. L., \& Wiseman, D. L. (1995). Laboratory and professional development schools. In L. W. Anderson (Ed.), International encyclopedia of teaching and teacher education (2nd ed., pp. 598-604). Oxford, England: Pergamon.

Stewart, F. (1996). Globalisation and education. International fournal of Educational Development, 16, 327-333.

Stofflett, R., \& Stoddart, T. (1992). Patterns of assimilation and accommodation in traditional and conceptual change teacher education courses. Paper presented at the meeting of the American Educational Research Association, San Francisco.

Sugrue, C. (1996). Student teachers' lay theories: Implications for professional development. In I. F. Goodson, \& A. Hargreaves (Eds.), Teachers' professional lives (pp. 154-177). London: Falmer Press.

Sultana, R. G. (2002a). Quality education and training for tomorrow's Europe: A contrapuntal reading of European Commission documents. In A. Nóvoa, \& M. Lawn (Eds.), Fabricating Europe: The formation of an education space. Dordrecht, The Netherlands: Kluwer.

Sultana, R. G. (Ed.) (2002b). Teacher education in the Euro-Mediterranean region. New York: Peter Lang.

Tarrant, J. (2000). What is wrong with competence? fournal of Further and Higher Education, 24(1), $77-83$.

Tisher, R. P. (1990). One and a half decades of research on teacher education in Australia. In R. P. Tisher, \& M. F. Wideen (Eds.), Research in teacher education: International perspectives (pp. 67-87). London: Falmer Press.

UNESCO (1998). World education report: Teachers and teaching in a changing world. Paris: Author.

Wain, K. (2004). The learning society in a postmodern world. New York: Peter Lang.

Weiler, K. (1997). Women and the professionalization of teaching. In L. J. Saha (Ed.), International encyclopedia of the sociology of education (pp. 721-725). Oxford, England: Pergamon.

Whitehead, J. (1995). Mentoring: A review essay. British fournal of Sociology of Education, 16(1), $129-133$.

Whitford, B. L., \& Metcalf-Turner, P. (1999). Of promises and unresolved puzzles: Reforming teacher education with professional development schools. In G. A. Griffin (Ed.), The education of teachers (98th yearbook of the National Society for the Study of Education, part 1, pp. 257-278). Chicago: University of Chicago Press.

Wideen, M., Mayer-Smith, J., \& Moon, B. (1998). A critical analysis of the research on learning to teach: Making the case for an ecological perspective on inquiry. Review of Educational Research, $68,130-178$.

Young, M. (1998). Rethinking teacher education for a global future: Lessons from the English. fournal of Education for Teaching, 24(1), 51-62.

Zeichner, K. M. (1993). Traditions of practice in U.S. pre-service teacher education programmes. Teaching and Teacher Education, 9, 1-13.

Zeichner, K. M., \& Noffke, S. E. (2001). Practitioner research. In V. Richardson (Ed.), Handbook of research on teaching (4th ed., pp. 298-330). Washington, DC: American Educational Research Association. 